Article

\title{
Education for a Sustainable Future: Strategies of the New Hindu Religious Movements
}

\author{
Martin Haigh \\ Department of Anthropology and Geography, Oxford Brookes University, Gipsy Lane Campus, \\ Headington, Oxford, OX3 0BP, UK; E-Mail: mhaigh@brookes.ac.uk; Tel.: +44-1865-483785; \\ Fax: +44-1865-483937
}

Received: 10 October 2010; in revised form: 8 November 2010 / Accepted: 10 November 2010 / Published: 17 November 2010

\begin{abstract}
Increasingly, sustainability is conceived as a crisis of the human mind and the key challenge for pro-sustainability education is developing sufficient motivation in learners. The spiritual aspirations of religious communities contain sufficient motivational force, which may be deployed for effective sustainability education. This paper explores the approaches to sustainability and sustainability education of some internationally-oriented Hindu religious movements. These include the rural education initiatives of Gandhian Sarvodaya, which emphasizes non-harming, self-reliance and personal ethics, ISKCON, which emphasizes devotional service, P.R. Sarkar's Ananda Marg, which emphasizes cooperative enterprise, the Tantric body re-imagined at the social scale, and Swami Vivekananda's Sri Ramakrishna Order, which emphasizes karma yoga, spiritual development through service to the God in each human. It also describes the British Hindu contribution to the UNDP/ARC's multi-faith sustainability initiative "Many Heavens, One Earth"; which is the "Bhumi Project" and its two main campaigns, Green Temples and Compassionate Living.
\end{abstract}

Keywords: community education; NGO; Hinduism; faith-based environmentalism; Sarvodaya; Gandhi; Vivekananda; PROUT; ISKCON; Ananda Marg; Karma Yoga; Bhakti Yoga; Bhumi Project

\section{Introduction}

Achieving effective education for sustainability, education that makes the issues and problems of sustainable living real and affective for all of the world's people, has been called the greatest challenge 
of our present age [1]. The issue is a struggle for hearts and minds whose goal is the construction of an ethic of personal responsibility towards the World. Even today, religion constructs the personal ethics and worldviews for the vast majority of the world's people, if not directly then indirectly through social and cultural tradition. O'Brien and Palmer [2] suggest that over $80 \%$ of the world's people profess some form of religious allegiance and that almost all are born into a set of beliefs and ethical values that frame their relationship with the world. Palmer and Finlay [3] write; "Ultimately, the environmental crisis is a crisis of the mind. And likewise, appropriate development is appropriate development of the mind. We see, do and are what we think and what we think is shaped by our cultures, faiths and beliefs". Of course, achieving pro-sustainability behavior requires two things: first is information, which exists in profusion but is largely ignored, so second, and more important, is motivation - the will to act [4]. The significance is captured by United Nations Assistant Secretary-General Olav Kjørven, who notes that the chief characteristic of the last 20 years of climate change negotiations has been 'everyone generally wanting to do as little as possible, while pushing for others to do as much as possible...to make sure that someone else pays the bill' [5]. Of course, this is not the way a religious community thinks. For example, the Hindu tradition is constructed upon the notion of Seva (service), which is work done not for personal gain but as a matter of duty or an offering to God.

This paper explores, briefly, the approaches to education for sustainability (ESD) being developed by four of the new Hindu religious movements in the West. These are the Ramakrishna Order of Swami Vivekananda, Gandhian Sarvodaya, ISKCON, the International Society for Krishna Consciousness or 'Hare Krishna' Movement, and P.R. Sarkar's Ananda Marg. In Nattier's classification, these are all 'Export' traditions that were brought to the West by Universalist strands within Hindu reformism [6]. They are not 'Baggage' traditions that arrived with different immigrant communities, like the Swaminarayan movements, nor are they "Import" traditions that were brought out of India by Western Gurus like Adi Da, although all are linked to the western New Age Movement [7].

In philosophical terms, three of these movements may be linked with Vedanta and with the three paths to liberation described by the Srimad Bhagavadgita [8,9]. The teachings of Swami Vivekananda lean toward jnana-yoga, the path of knowledge although like the Mahatma Gandhi, the practice of his Ramakrishna Order emphasizes karma yoga, the path of dutiful work. However, ISKCON is firmly based in bhakti yoga, the path of devotion and surrendered action. By contrast, the teachings of Sarkar represent a modern communal version of Tantrika [10], while Vaisnava Pancaratra texts are an important influence within ISKCON. All four are reformist and universalist movements that emphasize religious engagement above community, caste and/or birthright. All four movements have significant cadres of Western converts as well as diaspora supporters. All four demonstrate a degree of hybridization with Western cultural ideas and values including, in all cases but Sarvodaya—which remains mainly secular, the development of active, congregational communities [11,12]. Finally, this paper describes the ongoing Bhumi Project. This umbrella project represents a unique attempt to develop a united voice and united action plan for sustainability by Britain's scatter of (previously disconnected) Hindu congregations [13]. 


\section{The Ramakrishna Order: Service to the God in Every Human}

In 1893, Swami Vivekananda launched Hinduism as a World Religion in a speech to the Parliament of Religions in Chicago. His speech presented the Hindu tradition as promoting the unity of all people and as providing the heart of all religion [14]. After four years teaching and travelling in the USA, he launched the Ramakrishna Order and returned to India acclaimed as a hero-saint. In the West, Centers of the Ramakrishna Order, like the Vedanta Societies of Southern California and the UK, are leaders in the interfaith movement but tend to focus on teaching that emphasizes India's spiritual tradition of detachment [15]. Their Advaita Vedanta message asserts that all humankind, all existence and all Truth is One, a Universal consciousness. The apparent distinction suggested by the names and forms that we apply to the World are not the ultimate reality and, in fact, are illusory. Each human soul is divine and that divinity may be realized through detachment from the World [16]. However, Vivekananda adds that the process of Self-realization involves self development, which may be achieved "by controlling nature: external and internal. Do this either by work, or worship, or psychic control, or philosophy-by one, or more, or all these-and be free. This is the whole of religion. Doctrines, or dogmas, or rituals, or books, or temples, or forms, are but secondary details" [17]. Swami Vivekananda further advised his Indian followers: "With the help of Western science set yourselves to dig the earth and produce food-stuff-not by means of mean servitude of others-but by discovering new avenues to production, by your own exertions aided by Western science. Therefore I teach the people of this country to be full of activities, so as to be able to produce food and clothing for themselves. For want of food and clothing ..., the country has come to ruin-what are you doing to remedy this? Throw aside your scriptures in the Ganga and teach the people first the means of procuring their food and clothing, and then you will find time to read to them the scriptures. ... teach them first of all to make provision for food, and then teach them religion" [18].

For Vivekananda, "Education is the manifestation of the perfection already in Humans. Therefore, the only duty of the teacher ... is to remove all obstructions from the way" [19]. Following Hindu tradition, he offered that teaching is best conducted through a Guru, a teacher, who through empathy and example helps the learner rediscover their true Self through service and devotion [20]. Vivekananda's educational ideas involved whole-person character building through hard-work, learning through mistakes, but always service to the deity that lies within every human. "That education which does not help the mass of the common people equip themselves for the struggle for life, which does not bring out strength of character, the spirit of philanthropy, and the courage of a lion-is it worth the name?" [21].

Among many celebrated examples of their work, the Mission's "Integrated Abujhmarh Tribal Development Project: Sustainable Development for Ethnic Minorities” in Bastar District, Madhya Pradesh tackles rural uplift. UNESCO observes that the project succeeds "largely because of the holistic, integrated approach taken by the Mission" which extends from tackling the problems of the region (illiteracy, poor sanitation, poverty and ineffective agriculture) to their schools, which adopt "a similar integrated approach for the all-round development of learners" [22]. On a more grand scale, West Bengal's Ramakrishna Mission Lokashiksha Parishad takes the Mission's education in integrated rural development to more than 6,000 participants each year [23]. 


\section{Mahatma Gandhi: Sustainability through Sarvodaya}

Karma-yoga, the religious path of work that is performed, not for any expectation of material gain but as dharma, duty, is central to the teachings of Mahatma Gandhi and his followers. Gandhi argued that "Education does not mean knowledge of letters ... it means knowledge of duty... True education lies in serving others..." [24]. His formula for social and ecological justice was to live simply so that others can simply live. Following Hindu tradition, Gandhi considered that attachment to material things was the source of most human problems. The Srimad Bhagavadgita explicitly links materialism with the asuric (demoniac) tendencies that cause humans to become a burden upon the Earth [25]. This text calls anger, lust and greed the three gates to hell, and points out that all are born of desire for possession. Gandhi's solution was to devise a system of trusteeship to replace personal possession.

Beyond this, Gandhi built his version of education for sustainability on six concepts [26]. First is Truth, a synonym for God and the ultimate goal. Second is Ahimsa, which means non-harming. Most Hindus believe in the spiritual unity of all life. The doctrine of reincarnation implies that each spiritual 'self' is endlessly recycled through 8.4 million species of life according to the effects of its deeds in each life, its karma [27]. Vivekananda asked his followers to serve the divine spark contained within each human but, of course, that same spark exist in all creatures. The Srimad Bhagavadgita 18.20 states "That knowledge by which one undivided spiritual nature is seen in all living entities, though they are divided into innumerable forms, you should understand to be in the mode of goodness". Hence, Gandhi campaigned against meat-eating and for the rights of all creatures as well as against social prejudice. His famous method of civil non-cooperation protest, Satyagraha, represented the simultaneous realization of Truth and Ahimsa in the management of human affairs and it relied on 'Truth-force', the power of the moral high ground, to shame and transform wrongdoers [28]. Gandhi's fourth principle is Swaraj, which means self-rule - a term from India's struggle for independence. This Gandhi interpreted as self-control; a goal for each community and each individual. Fifth is Swadeshi, 'bread labor', a universal duty to engage in productive labor that also aims to undermine the notion that manual tasks (and those laborers who perform them) are inferior [26].

Finally, together, these inspired Gandhi's political economic system-Sarvodaya [29]. Acharya Vinoba Bhave [30] summarizes Sarvodaya's goals as: capable people directing their capacity to service of others; people fully self-dependent and cooperative with non-violence as the social interaction. Additionally, decades ahead of its time, Gandhian Sarvodaya sought balance and aimed for stability not growth [29]. Like modern sustainability thinking, it emphasized sustainable local production rather than the unsustainable long distance transport of goods and it emphasized quality rather than quantity in all matters. It promoted social egalitarianism through small scale enterprise and pluralism to avoid class, caste, inter-community and employer-employee antagonisms. It preferred handicraft to factories, which were seen as sources of social inequity. It advocated decentralized governance to reduced oppression from distant administrations. In fact, it contained a vision of self-sufficient village republics living in harmony with their habitat. Khoshoo's ten principles of Gandhian Environmentalism update these ideas for the present time [12,31]. Collectively, they emphasise: humanity's unity and oneness with nature, self-discipline, ethical altruism, non-violence, local self reliance and the bottom-up approach to development [31]. 
The zeitgeist of Sarvodaya is captured by the title of J.C. Kumarappa's pioneering book: "The Economy of Permanence" [32]. Decades ahead of the schools of Clare Graves [33] and Ken Wilber [34], Kumarappa recognized three levels of human civilization, each dominated by one of Samkhya-Yoga's three modes of nature: Tamas-Ignorance, Rajas-Fruitive activity, and Sattva-Serenity, stability and goodness [35]. First is the 'Animal' stage, when economies are unthinkingly parasitic upon their habitats. Second is the 'Modern' stage of societies that are creative, materialistic and energetic in their ever-expanding exploitation of resources. Third is an advanced, spiritual, "Economy of Service". "The highest form of economy in Nature... is best seen in the relation between the young one and the parent. The mother bird will scour the jungle and risk its life in defending the young from its enemies. It functions neither for its present need nor for its personal future requirement, but projects its activities into the next generation, or generations to come, without looking for any reward" [32].

In India, the tide of Sarvodaya activism rises and falls. In the 1950s, Acharya Vinoba Bhave's Bhoodan (land gift) program involved more than 1.6 million hectares and 1 million people. His Gramdan (community gift) program affected 140,000 villages, not always with lasting success [36]. Sarvodaya was also the power behind the growth of India's indigenous environmental movement, beginning with the "Chipko" Hug the Trees campaign of the late 1970s and 1980s [37,38]. However, Sarvodaya's most dramatic development was in Sri Lanka. Here, A. T Ariyaratne built a 15,000 village, grass root, self-help, development program based on Gandhian ideals mediated through Buddhism [39]. Sarvodaya Shramadana aims integrate spiritual and social development focusing on engaging the young and communal project work [40].

Long before the Green Movement in the West, Gandhi's followers recognized that Western materialism, with its cults of personal possession and perpetual growth, was the greatest threat to sustainable living. "The most sophisticated danger... is the modern Western framework of thought" [41], which is why they "propose a new education... a new way of living" [42]. Like Sarvodaya, Nai Talim (New Education) sought the elimination of social problems, especially poverty and the creation of a local, self-sustainable productive base. It aspired to create skilled learners with useful knowledge who lived by the principles of Truth and Ahimsa. It sought to produce learners who were integrated into community life through engagement in productive work and who desired to undertake service for humanity. It tried to find self-realized acharya teachers, whose lives would be "signposts that dissolved the need for words" [43].

Of course, Gandhian thought has been hugely influential in both the Peace Education and Green Movements [44]. As the Guru of Deep Ecology, Arne Naess, notes: "Gandhi's utopia is one of the few that shows ecological balance, and today his rejection of the Western World's material abundance and waste is accepted by progressives of the ecological movement” [45]. Indeed, Deep Ecology Pedagogy has deep roots in Gandhian Hindu thought, most notably, its goal of Ecological Self-realization, which is reached by expansion from a realization of the small personal self identity - as in childhood, through the reframing of identity that comes with recognition of the social Self, the self as a component of a larger human community - as in adolescence, to realization of the ecological Self, as a part and parcel of the community of all life on Earth [46,47]. Each step reduces the amount of the universe that can be called external and shifts perception 'I am working to protect the ecosystem for my (individual) self' 
to the more pro-sustainability stance of 'I am part of the ecosystem working to protect my (Ecological) Self' [48].

\section{P.R. Sarkar, PROUT and the Ananda Marg}

P. R Sarkar was the founder of the Neohumanist Philosophy-PROUT, (Progressive Utilization Theory) and, as Shri Shri Ananda Murti, Guru of the Ananda Marg or Path of Bliss religious movement. His approach was, like that of the West's Deep Ecology, a path of expansion, but one that reached beyond the transition from the personal to Ecological Self toward the cosmic Self. Sarkar writes "The scientific process of expansion of mind is called Tantra. Tantra ... literally means to attain liberation through expansion" [49], although it was Sarkar who shifted this from being an individual to a collective act. He contrasts his approach with materialism. "Suppose a person is trying to expand the mind, not to attain Parama Purusha, [The Supreme Consciousness] but a crude goal such as name, fame or wealth.... One ... becomes mentally degenerated... as crude as matter. A person whose mind is engrossed in money becomes money itself' [50]. The Western tradition of describing someone as their occupation recognizes this process. A human becomes objectified and limited as a plumber, a Geography Teacher, or an administrator rather than person.

The less unusual aspect of Sarkar's teaching, however, are influences from the revolutionary ideologies of Communism, whose failures had given a bad name to the revolutionary mobilization of the people. Like Gandhi, Sarkar proposed a new revolutionary doctrine. His Progressive Utilization Theory, PROUT, a kind of spiritual socialism is based on 5 principles. First, no one should accumulate individual wealth except by permission of the community. Second and third, there should be maximal rational use of all the potentialities in the world, be they material, super-mundane or spiritual and the same for humans and human societies. Fourth, peoples' roles in society should be developed in way that balances the spiritual and material and, fifth, implementation should also be balanced, humanitarian and progressive [51]. Learning from the collapse of Communism "An important goal of PROUT is to encourage individuals to realize their full potential and achieve their dreams..." [52].

The Ananda Margis are active in promoting sustainable development [53]. Maheshvarananda argues that there are six keys to a better world: 1. A Just Economy; 2. Community; 3. Ecology, which means recognizing the rights of all living creatures including animals and plants; 4. Ethics; 5. Ideal Leadership; and 6. Spiritual Values [54]. The PROUT approach to sustainable development contrasts with the Gandhian model, which is based on the notion of the village republic, by using the extended family as its model. Activist Krishna Ragu, working to apply these precepts in Venezuela, avows that "PROUT is the application of the family spirit to society" [55].

The PROUT Model has several stages. First, as with Vivekananda, there is the goal of meeting basic needs. However second, and contrary to most sustainability thinking, is a drive to grow production to generate increasing purchasing capacity and increased leisure time through efficiency gains. More conventionally, there is a commitment to community-based, decentralized planning and the development of a three tier economic system, which limits private enterprise to very small concerns and Government control to very large, while the bulk is conducted through cooperative societies. PROUT researchers work hard at enhancing the effectiveness of cooperative enterprises and this work lead their aim of creating local economic self-sufficiency as in Sarvodaya. A key objective is 
Economic Democracy. This involves the social control and regulation of wages, both minimum and maximum within a fairly narrow range and its final goal is spiritual development to shift the peoples' priorities away from materialism and greed and towards the construction of spiritual wealth and well being. The approach is resolutely bottom-up and targets first the poorest communities [56].

PROUT's approach to sustainability and education follows a similar path to its predecessors, which is that of karma yoga. However, it engages more overtly with the education of the karma-yogi, karma sanyasa or sadvipra. This is a spiritual revolutionary who, through spiritual discipline and transformative practices, realizes the supreme consciousness and yet remains engaged in service work for social uplift and, more or less coincidentally, with habitat sustainability [57]. Describing the transformative spiral of PROUTist education, Marcus Bussey characterises the sadvipra as an acharya and change agent: "an individual who brings, through their moral and intellectual courage, a transformative shift to society" [58]. This PROUTist curriculum embeds its own Deep Ecology. Australian practitioner Alister [59] notes that when a learner: "actually feels oneness with all things, that experience can have a lasting effect. When you have deeply felt, 'I am one with the trees, birds, earth, all the children of the world.' it becomes even more vital to protect and fight for their rights and survival'. Like Gandhi, Sarkar also encouraged his followers to revolutionary activity by participating in ecological, farmers' movements and anti-capitalist workers movements, but unlike Gandhi, the Ananda Marg has not always avoided the taint of violence.

PROUT education strives to combine local action with global awareness. In 2009, Acharya Ghista set out ambitious plans for an Ananda Marg Gurukula University, which would teach enlightenment as well as knowledge and educate ideological change agents to lead the transformation of society by local action, grass roots sociology, politics and work towards creating sustainable communities and global thinking. The goal would be to create a new Geopolitical order that would allow political autonomy and sustainability to all countries [60]. The new curriculum does not emphasize sustainability but its special programs would include: Equitable Globalization, Ecology and Environmental Protection, and Renewable Energy. More generally, writers associated with Sohail Innayatullah, Marcus Bussey and Ivana Milojevic, have worked to build a distinctive Neohumanist model of education, especially in the realm of Futures Studies [61].

Like Swami Vivekananda, P. R. Sarkar believed in a universal approach to education that blended and balanced the objective, materialist, approach of the West with the subjective, spiritual approach of the Indian tradition. He writes that: "the West is completely obsessed with physical development. It has made spectacular progress in the fields of politics, economics, science, warfare, etc. ... But for all that, it is not socially content and miserably lacks spiritual wealth ... which has created a crisis. Therefore, it is abundantly clear that no country can progress harmoniously with only one-sided development....In the educational system of the East, there is the predominant element of spirituality... students ... led a strictly ethical and spiritual life and were mainly taught ...spiritual knowledge and ... so the people ... could not but be spiritual in their thoughts and actions. Whereas there is, in the western system of education, a clear and unilateral emphasis on mundane knowledge... to build up an ideal human society in the future, the balanced emphasis on the two is indispensable" [62]. 


\section{ISKCON: The Way of Devotional Service}

Vedic tradition, of course, is the episteme from which all these movements arise. However, nowhere is it more strongly emphasized than in the most openly theistic of the four movements discussed here, ISKCON, better known as the Hare Krishna Movement. Like Gandhi, this is Vaisnava in orientation. However, its means is devotional service (bhakti) and its goal is eternal, transcendent association with 'the Supreme Personality of Godhead', which they identify as Sri Krishna. This Bhaktivedanta tradition, which emerges from Bengali (Gaudiya) roots, marks the teachings of disciples of the Sage Chaitanya, who is regarded as the Golden Avatar of Sri Krishna, and those of Srila A.C. Bhaktivedanta Swami Prabhupada, who brought the ideology out of India and founded a movement in the West. Subsequently, this has permeated the Hindu diaspora and embedded itself back in India's major cities [63].

ISKCON's core scriptures are the Bhagavadgita and the Srimad Bhagavatam, especially Book 10, which describes the rural idyll of Sri Krishna's youth as a cowherd in the river-side forests of Vrindavan and his romantic associations with Srimata Radharani and her friends [64]. The settings for these pastimes, described in glowing detail, are considered to be descriptions of Sri Krishna's transcendental heaven, Goloka, carried into the material realm for Sri Krishna's sojourn on Earth. Clearly, these are the landscapes that God loves and so devotees may win closer association to God by making their habitat on Earth as heaven-like as possible, so allowing the expression of its Divine Nature [65]. The tradition accepts that Sri Krishna has created everything, everybody, even time itself, from a small part of His transcendental person. So, Sri Krishna is the Truth underlying the material world, whose reality is no greater than that of a virtual world or video game. Mundane existence is a kind of "Second Life" and, of course, there are better things to be done in the "First Life" that contains it.

Scripture also describes the process for education and sustainable living, which is again expressed in terms of service. In fact, the Gaudiya Vaisnava's prayer is to remain, eternally, a servant of the Supreme. Inevitably, their final position is that actions should be undertaken as an act of devotion, surrendered service to God, whose grace alone can grant Self-realization and eternal happiness. In the Bhagavadgita 18.55, Sri Krishna states: "One can understand me as I am only by devotional service. And when one is in full consciousness of Me, by such devotion, can enter heaven" [66]. Their challenge, like that of the Heroic Arjuna to whom the Bhagavadgita is propounded, is only to identify the nature of the service that Sri Krishna has prepared for them.

Being an organization with strong Western roots, ISKCON, is very concerned about its authenticity and, as a consequence, its spiritual leaders are strongly attracted to ancient Vedic ways of existence. This aspect applies to both their approach to education and sustainable living. Inevitably, the movement stresses 'simple living and high thoughts' and encourages its devotees to construct spiritual development rather than material wealth [67]. There is a commitment to the Vedic Guru model of education, where the teacher is an Acharya, someone who is a role model and whose life-example is also their teaching, an approach also demonstrated strongly by the Acharya Vinoba Bhave. ISKCON is primarily urban in membership but, its spiritual leader, Srila A.C. Bhaktivedanta Swami Prabhupada, a former Gandhian Sewak, wanted to give up the cities, where living is 'abominable', re-establish a society based on rural village communities on Vedic lines, and help people to limit their perception of 
wants to their real needs [68]. In respect of this, ISKCON supports more than 50 rural communities, each seeking to be a model of self-reliant self sustainability, with most oriented to cruelty-free cowherding, and all notable for having replaced their tractors with oxen. In promoting their vision of Isavasya (God Centered) agriculture, HG Rupanuga dasa argues that "This God-centered attitude does not reflect a 'primitive' agrarian culture or mentality...[but] a life-style that's in real harmony with the ideals of sustainable living" [69]. ISKCON also promotes Vanashrama Dharma, which is recognition of the four divisions of society, which, although originally based on the disposition of the individual, subsequently gave rise to the hereditary caste system with its inherent problems. However, ISKCON's GLOVESCO offshoot suggests that this is a route to a classless society and a basis for an education based upon their Vedic hierarchy of human needs [70]. These are first, spiritual needs, satisfied through devotion, second mental and emotional needs satisfied through Brahminical culture, and third physical needs, which are satisfied through land protection and cow-herding. Varna is assigned through observation, psychological testing, astrology, and, of course, heredity. Brahmanas study, teach and worship, Kshatriyas acquire, administer, develop, share and protect, Vaisyas conduct agriculture and commerce, whilst Sudras engage in labor and crafts. Education is tailored to the needs and aptitudes of each group. Brahmanas and Kshatriyas would be educated, formally, in Sanskrit scriptures, whilst Vaisyas and Sudras would undergo applied scientific and vocational training or apprenticeships, mainly through non-formal instruction. Society would be segregated by gender, with females undergoing training in the 64 arts prescribed by the scriptures [70]. The aim, therefore, is to make a return to the self-sustaining 'Golden Age' of Vedic Civilization and it is intriguing that this exposition is produced by a Swami of French-Canadian origins, although these same ideas resurface fairly regularly in the speeches of Indian politicians. Similar ideas are found in Sahadeva dasa's four aspects for an alternative future, which are based on Self-realization, worship - meditation, cow protection, 'enlightened' or organic agriculture and 'thinking small' or voluntary simplicity of life [71].

Other projects with ISKCON influence, however, have a more conventional aspect. For example, the Working Villages International NGO's Ruzizi Valley Project in DR Congo, emphasizes full employment, feeding the workers, low-input organic agriculture and self-sufficiency at the village level, including village-based vocational training [72]. Here, Hindu and ISKCON influence is not emphasised and the keyword is the Gandhian concept of Swadeshi, which is interpreted as localized economics [73]

Meanwhile, ISKCON remains a mainly urban phenomenon. In recent decades, it has completed a transformation from being, primarily, an ashram-based organization serving Western converts, to a congregational organization serving the Indian diaspora [74]. In this later form, and increasingly interacting with the sensitivities of its congregation, ISKCON has become involved with work that seeks to promote pro-sustainability behavior among its urban householder supporters. For example, in recent years, ISKCON (UK) has promoted two campaigns. One is the Ahimsa campaign devoted to encouraging the better treatment of cows and the production of 'cruelty free', ethically pure, milk [75]. The other is 'Karma to Climate Change' (K2CC), which is about making the lifestyles of the congregation more sustainable [76]. The $\mathrm{K} 2 \mathrm{CC}$ educational experience is provided by a tented exhibition that travels religious festivals. It includes a series of exhibits, tableaux and audio-visual presentations, a lifestyle-choice questionnaire, and a consultation session where respondents discuss possibilities for lifestyle change and their personal feelings about sustainability issues. Its final step is 
a 'pledge tree' where visitors are given the opportunity to make a public and sacred pledge to make one or two changes in their lives. Thus far, >1000, mainly multigenerational family groups, have left records $[76,77]$.

K2CC was created in an attempt to overcome the British Government's view that their Hindu minority is 'hard to reach'. It showed that while British Hindus might be hard to reach through the values and language of middle England, they were accessible to their own tradition. The project succeeds by translating standard ecological footprint analysis into something that resonates with Hindu people. Its keyword is karma, the Hindu notion that every action in the mundane world creates a shadow such that good actions lead to good consequences and bad actions to bad consequences both and the scale at the individual and society at large. This is linked to the notion that the problems that burden the Earth are the result of the sum of a billion small decisions made by individuals in human societies. It recalls that Sri Krishna incarnated, partly, in response to a request from the Earth, who wanted relief from her burden of uncaring and selfish people [78]. Of course, it is difficult to evaluate the larger impact of such works but the large number of pledges show families targeting small strategic environmental improvements in their family's way of being (better home insulation, greater energy efficiency, a move towards green energy and organic produce), often with an eye to conforming with the higher standards of their community. Today, $\mathrm{K} 2 \mathrm{CC}$ and its cousins are part of a much larger pan-Hindu initiative on sustainability, the Bhumi Project.

\section{Bhumi Project}

In April, 2009, the leaders of the UK's four largest Hindu temple congregations met together for the first time at the Oxford Centre for Hindu Studies. The outcome was agreement to work together and produce a Hindu contribution to the interfaith Alliance of Religions and Conservation (ARC)/UNDP program: "Plans for Generational Change" [79,80]. In fact, most of these organizations were already involved in pro-sustainability education. Active projects included "Go Veg(etarian) Go Green" and "Be the Change" campaigns from the BAPS Swaminarayan Sanstha, London [81], ISKCON's K2CC and the work of the Sri Venkateswara (Balaji) Temple, West Midlands, UK, whose whole 5 hectare temple complex is reclaimed from former industrial wasteland [82]. From the formal education sector, the National Forum of Hindu Students described attempts to 'green' their annual conferences while, Britain's first state-supported Hindu faith school, the Krishna-Avanti Primary School, explained that environmental responsibility was a key aim [83]. From these and subsequent discussions with many further Hindu communities, the Bhumi project was drafted and included in the suite of "Plans for Generational Change" set before the UN Secretary General at Windsor Castle, UK, in November 2009.

The Bhumi project's mission statement emphasizes service for the environment, compassion, education and partnership for sustainability [84]. Currently, the project has two foci; Green Temples, which aims to have the temples set a good example, and Compassionate Living, which aims to change the lifestyles of devotees in the wider community. The Green Temples campaign includes five steps beginning with greener worship, using locally gown and organic fruit and flowers, gardening to produce home grown food, greening festivals by demonstrating good practice through recycling, greening pilgrimage journeys by using public transport, and more ecological disposal and recycling of sacred waste. The Compassionate Living program for the wider community has its own five steps. 
These involve dietary change: cutting out red meat to reduce our carbon footprint, adopting a vegetarian diet on ethical grounds, promoting better treatment of animals - as in the Ahimsa Cruelty Free Milk project, and ethical purchasing and shifting towards a life-ethic based on compassion for all the living world [84]. The plan is to roll out the project first to the British Hindu Community, using festivals as the vehicle, and then to the balance of the Hindu World, with the first step being a presentation to temple presidents in India in late 2010.

\section{Discussion}

The World's religions have enormous potential for promoting sustainability. They affect an enormous number of people. Hinduism alone reaches 0.9 billion, although the diaspora is no more than 15 millions. By contrast, Christianity claims 2.1 billion, Islam -1.5 billion and Buddhism -0.4 billion $[85,86]$. These beliefs are also major motivational factors in the lives of many adherents. ARC argues that sustainability lies at the heart of "what most of the world believes" [80]. It guides ethical positions, daily lives and planning for the future [87]. At the global scale, religion is already a major influence on green thinking but its potential is colossal.

Reading the globalised literature of the West, one could be forgiven for thinking that only Western religions and agencies were engaged with sustainable development and sustainability education. As Paulo Freire noted, there is a tendency for dominant sectors of society to ignore the voices and deny dialogue to outsiders [88]. Krishna Kumar also comments on the colonial mindset that infects many former colonies, which defines 'educated knowledge' as that known to the elite and so relegates the knowledge sets of others to the periphery [89]. He writes: "It so happens, obviously due to the economic and political dynamics of our society, that ignorance of her system is an attribute of my image as an educated man. I am not supposed to know... On the contrary, her ignorance of the Western ... is a proof of her lack of education because knowledge of the Indian ... is not one of the attributes of the educated Indian in postcolonial India" [90]. This paper is written, partly, to change this impression. It deals with the sustainability education and works of four modern international Hindu Religious Movements; all belonging to Nattier's class of Export traditions [6]. It addresses two foundational traditions, Gandhian Sarvodaya and Vivekananda's Ramakrishna Order, whose combined influence is huge. It is written: "Modern Hindus derive their knowledge of Hinduism from Vivekananda, directly or indirectly" [91], while Gandhi remains an iconic figure. It continues to consider the work of two sustainability-engaged modern movements, ISKCON and Ananda Marg/PROUT, and concludes with a brief look at the pan-Hindu Bhumi project, a British diaspora initiative. It summarizes the ideas on education and sustainability of these more internationally visible Hindu movements but, of course, it misses out many more. These include the works of the followers of Sri Aurobindo and the Mother, who have developed and practice an influential system of 'Integral Education' [92,93] and the Brahma Kumaris, who have their 'Living Values Educational Programme' [94]. There are also Sri Sri Ravi Shankar's Shaivite “Art of Living” Foundation's 'Deepening Roots' projects [95], Satya Sai Baba's 'Educare' programme, where sustainability thinking is constructed from the five core human values of truth, right conduct, peace, love and non-violence [96] and many more. Outside these 'Export' traditions, there is also much work going on in traditions that Nattier 
classifies as 'Baggage', because they arrived with particular immigrant communities, like the followers of Bhagwan Swaminarayan [97].

This review does not tackle the issue that these pro-sustainability activities feature, disproportionately, the works of Western converts and second generation members of the Indian diaspora. (There are parallels here with such as India's Swadhyaya Movement, which engages town dwellers in travelling to help village development as 'Bhaktipheris', those engaged in travel for devotional service [98]). It could be argued that some of these developments reflect the Hindu absorption of aspects of a Western value set. The counter argument, of course, is that the Western 'Green' value set, especially where it engages with spirituality, has its own very deep roots in the work of Gandhi [47] and other Dharmic traditions, especially Buddhism [99].

Meanwhile, these movements are tackling the most fundamental problem of education for sustainable development. This is the problem of providing a sufficient motivation, enough good reason, why an individual human should act in cooperative and altruistic ways [100]. The driving motivation of conventional Western society remains the acquisition of material wealth and individual success-It reifies personal greed, perhaps extended to the benefit of a family or clan. Green thinking in the West stresses ethics and personal sensitivity, a sense of fairness and justice, but these are often dismissed as luxury items in the struggle for survival. This weakness also affects Gandhi's model, which aims for the moral high ground and adopts the difficult position that it is better to be sinned against than to sin yourself through violence [28]. The Srimad Bhagavadgita 14.16 points out that: "The result of pious action is pure and is said to be in the mode of goodness. But action done in the mode of passion results in misery, and action performed in the mode of ignorance results in foolishness" [66]. Unfortunately, it is easier and, despite the longer term consequences, more immediately satisfying to be selfish or to tackle a problem through violence and the gentle steer of 'guided idealism' is not enough to offset this [87]. However, these movements, which emphasize karma-yoga, self-purification through service to the world, do provide a transformative educational motivation for self-development that can be lived and that does offer sufficient depth and reward in a superficial and mercurial world.

Of course, Swami Vivekananda urged his followers to: "set yourselves to dig the earth ... by discovering new avenues to production, by your own exertions aided by Western science...be full of activities" [101]. Elsewhere, Rabindranath Tagore urges each learner to become a world-maker, a "Visvakarman", who demonstrates the "union of education and life" and acts for the welfare of all [102,103], while Gandhi talks about followers 'establishing the kingdom of Rama in their own hearts' [104], Rama, of course, being the Lord of Dharma, or right action. Such thoughts rather undermine the conventional Western wisdom that Hinduism is about detachment from Worldly affairs. In fact, it teaches detachment only from the material results of engagement with the world. Sarkar agrees 'One should undergo penance for others' welfare, for the well-being of the world; and the good that the world enjoys due to one's sacrifice is the reward. One should not expect any reward greater than this. The good result of a good action is the reward of that action.... Human beings have come onto this earth to do something good...This is the reason why Vivekananda said, 'As you have come to the world, you must leave some mark behind' That is, you must do something which will do good to human society..." [50].

ISKCON, a devotional sect, naturally asserts a classically Hindu religious motivation, again taking their lead from the Bhagavadgita. Their approach is deeper than the karma-yoga notion that actions 
should be undertaken without regard to their results but simply out of a sense of duty. Like the 'Gita itself, their final position is all actions should be undertaken as service to God, whose grace alone can grant liberation from the endless cycle of death and rebirth. Once again, in the West, the Hindu ethic of self-purification is often misinterpreted as 'selfishness', when its true aspect is an ethic of personal responsibility, which is the grail of all that sustainability education that accepts that the chief threat to the welfare of the future is the uncaring human mind [4,105].

Ultimately, the main importance of the work described lies in its spiritual aspect and that it demonstrates the value of religion in sustainability education. As in all religion, the aim is to be affective and it provides motivations deeper than the material here and now. It works on the individual and their desire for self-justification as 'a good human being' and it embeds the self-realization of the interlinked unity of all existence. Its greater benefits accrue, however, not from reducing religious motivation to winning reward in heaven but, from extending religious concern to action in the world. Here, the Hindu concept of dharma, right action, is extended to service of the God in every human (Vivekananda), to the development of the social body (Ananda Marg), to living gently upon the Earth and building spiritual not material wealth (Gandhi), to service to God, who is the world and who appears to relieve the burdens of the Earth, and to help the Earth be as heaven-like as possible (ISKCON).

\section{Conclusions}

Our main environmental problem is the human arrogance that puts immediate human, often personal, welfare above the long term needs of either future generations or the habitat [106]. ESD concerns a re-examination of our ways of living; it aspires to be a whole life process that encompasses all of the things that matter to people, including their faith [107]. As Emma Tomalin warns: "no religion, Hinduism included, influences people's behavior and actions in a straightforward and predictable manner" [108]. However, collectively, the ESD of the new Hindu Religious Movements offer spiritual alternatives to material wealth and a set of social values that is much more in tune with the needs of the environment. Hinduism tends to regard the material world as subordinate and subsequent to a universal consciousness. Its approach to sustainability, while it may downplay the machineries of the organic environment and ignore the technologies of environmental protection, goes straight to the core of the current problem of the Western world. This may be excellent at science and technology but struggles with the problem of mind. As Orr reminds us, the main problem of the day is to make human minds fit for a living planet with limited resources [105]. P.R. Sarkar agrees that: "The practice of morality should be the most important subject in the syllabus at all levels" and he is explicit that this moral responsibility extends to all forms of life [109]. In fact, all these new Hindu Religious Movements agree that the key to achieving environmental sustainability is the spiritual awakening of the individual self and its breaking of its bonds of attachment to the objects and desires of the material world. In Education for Sustainability, the greatest problem is the way that humans are encouraged to think by modern society. When Gandhi said that there is enough in the world to meet the needs of every person but not enough for the greed of a single person, this is the problem he had in mind. Meanwhile, these Hindu Movements are working toward new styles of sustainability 
education that avoid the selfish materialism of Globalised society and, instead, build upon a religiously-motivated construction of spiritual wealth through selfless service to society and nature.

\section{References and Notes}

1. Annan, K. Secretary General Calls for Break in Political Stalemate over Environmental Issues, 15 March 2001; United Nations Press Release SC/SM/7739; Available online: http://www.un.org/News/Press/docs/2001/sgsm7739.doc.htm (accessed on 25 April 2009).

2. O'Brien, J.; Palmer, M. The Atlas of Religion: Mapping Contemporary Challenges and Beliefs; Earthscan: London, UK, 2007; pp. 14-15.

3. Palmer, M.; Finlay, V. Faith in Conservation: New Approaches to Religions and the Environment; The World Bank: Washington, DC, USA, 2003; p. xv.

4. Coward, H. Ethics and nature in the World's religions. Wissenschaftsethik und Technikfolgenbeurteilung 2002, 19, 91-109.

5. Kjørven, O. Quoted in: Many Heavens, One Earth: Faith Commitments to Protect the Living Planet; Colwell, M., Finlay, V., Hilliard, A., Weldon, S., Eds.; Alliance of Religions and Conservation: Bath, UK, 2009; pp. 15-16.

6. Nattier, J. Buddhism comes to Main Street. Wilson Quart. 1997, 2, 72-81. Available online: http://buddhism.lib.ntu.edu.tw/FULLTEXT/JR-ADM/nattier.htm (accessed on 1 March 2010).

7. Drury, N. The New Age: Searching for the Spiritual Self; Thames \& Hudson: London, UK, 2004.

8. Bhaktivedanta Swami, A.C., Prabhupada. Bhagavad Gita as It Is, 2nd ed.; Bhaktivedanta Book Trust: Los Angeles, CA, USA, 1986.

9. Sharma, R.N. Neo Vedanta Education; Shubhi: New Delhi, India, 2002.

10. Bussey, M. Where Next For Pedagogy? Critical Agency in Educational Futures. Ph.D. Thesis, University of the Sunshine Coast, Maroochydore, Australia, 2008. Available online: http://research.usc.edu.au/vital/access/manager/Repository/usc:4521 ?query=Bussey (accessed on 20 July 2010).

11. Bauman, C.; Saunders, J.B. Out of India: Immigrant Hindus and South Asian Hinduism in the USA. Relig. Compass 2009, 3, 116-135.

12. Singh, R.P.B. Mahatma Gandhi's Vision of Sustainable Development: A Lesson for Indian Geography. In Uprooting Geographic Thoughts in India: Toward Ethics, Ecology and Culture in 21st Century; Singh, R.P.B., Ed.; Cambridge Scholars Publishing: Newcastle upon Tyne, UK, 2009; pp. 192-223.

13. Hinduism: The Hindu Nine Year Plan. In Many Heavens, One Earth: Faith Commitments to Protect the Living Planet; Colwell, M., Finlay, V., Hilliard, A., Weldon, S. Eds.; Alliance of Religions and Conservation: Bath, UK, 2009; pp. 143-145.

14. Vivekananda. Addresses at the Parliament of Religions, 1893. In The Complete Works of Swami Vivekananda; Advaita Ashrama: Kolkata, India, 1989; Volume 1, pp. 1-25.

15. Jackson, C.T. Vedanta for the West; the Ramakrishna Movement in the United States; Indiana University Press: Bloomington, IN, USA, 1994. 
16. Atmasthanandaji Maharaj. Service in the Name of God in Every Human; The Telegraph: Calcutta, India, 2 April 2009; Available online: http://www.telegraphindia.com/1090402/jsp/calcutta/ story_10758025.jsp (accessed on 20 July 2010).

17. Ramakrishna-Vivekananda Center of New York Homepage. http://www.ramakrishna.org/ c_teach.htm (accessed on 20 July 2010).

18. Vivekananda. Conversations and Dialogues, Belur Math 1899. In The Complete Works of Swami Vivekananda; Advaita Ashrama: Calcutta (Kolkata), India, 1989; Volume 7, p. 183.

19. Vivekananda. What we believe in, 1894. In The Complete Works of Swami Vivekananda; Advaita Ashrama: Calcutta (Kolkata), India, 1989, Volume 4, p. 358.

20. Vivekananda. Conversations and Dialogues, Belur Math, 1898. In The Complete Works of Swami Vivekananda; Advaita Ashrama: Calcutta (Kolkata), India, 1989; Volume 7, p. 147.

21. Sharma, R.N. Neo Vedanta Education; Shubhi: New Delhi, India, 2002; pp. 61-81.

22. APPEAL Resource \& Training Consortium (ARTC). Innovations in Non-Formal Education: A Review of Selected Initiatives from the Asia-pacific Region: Non-formal Education for Sustainable Development; UNESCO: Bangkok, Thailand, 2002; pp. 46-51; Available online: http://www2.unescobkk.org/elib/publications/INFE/p34-51.pdf (accessed on 21 July 2010).

23. Chakraborty, S; Mandal, B.; Das, C.; Satish, S. Ramakrishna Mission: Research education and training in a farming systems context. In Non-Governmental Organizations and the State in Asia: Rethinking Roles in Sustainable Agricultural Development; Farrington, J, Lewis, D.J., Eds.; Routledge: London, UK, 1993; pp. 115-122.

24. Gandhi, M.K. Gandhi on Education; Rajput, J.S., Ed.; NCERT: New Delhi, India, 1998; p. 2.

25. Bhaktivedanta Swami, A.C., Prabhupada. Purports and translation for Bhagavadgita 16.11-15 and 22-23. In Bhagavad Gita as It Is, 2nd ed.; Bhaktivedanta Book Trust: Los Angeles, CA, USA, 1986; pp. 669-677.

26. Richards, G. Philosophy of Gandhi; Curzon Press: London, UK, 1982.

27. Bhaktivedanta Swami, A.C., Prabhupada. Purport to 7.10. In Bhagavad Gita as It Is, 2nd ed.; Bhaktivedanta Book Trust: Los Angeles, CA, USA, 1986; p. 334.

28. Naess, A. Gandhi and Group Conflict: An Exploration of Satyagraha's Theoretical Background; Universitetforlaget: Oslo, Norway, 1974.

29. Doctor, A.H. Sarvodaya: A Political and Economic Study; Asia Books: London, UK, 1967.

30. Bhave, V. The politics of non-violence. In School of Non-Violence; Kumar, S., Ed.; Martin Luther King Foundation/Christian Action/Housmans: London, UK, 1969; pp. 26-50.

31. Khoshoo, T.N. Gandhian Environmentalism: An unfinished task. IASSI Quart. 1997, 16, No. 1; Available online: http://www.mkgandhi.org/articles/unfinish_task.htm (accessed on 5 November 2010).

32. Kumarappa, J.C. The Economy of Permanence; Sarva Seva Sangh Prakashan: Rajghat, India, $1984 ;$ p. 9.

33. Beck, D.E.; Cowan, C.C. Spiral Dynamics: Mastering Values, Leadership, and Change; Blackwell: Malden, MA, USA, 1996.

34. Wilber, K. Integral Sprituality; Integral Books: Boston, MA, USA, 2006. 
35. Jacobsen, K.A. Prakrti in Sāmkhya-yoga: Material Principle, Religious Experience, Ethical Implications; Peter Lang Verlagsgruppe, New York \& Motilal Banarsidass: New Delhi, India, 1999.

36. Bhave, V.; Thorner, D.; Shah, C.G.; Choudhuri, M.; Oomen, T.; Ranadive, B.T. XIII: Bhoodan and Gramdan Movements. In Rural Sociology in India, 5th ed.; Desai, A.R., Ed.; Popular Prakashan: Mumbai, India, 1978; pp. 627-688.

37. Right Livelihood Awards. The Chipko Movement (India), 1987; Available online: http://www.rightlivelihood.org/chipko.html (accessed on 12 September 2010).

38. Haigh, M.J. Understanding Chipko: The Himalayan people's movement for forest conservation. Int. J. Environ. Stud. 1988, 31, 99-110.

39. Macy, J. Dharma and Development: Religion as Resource in the Sarvodaya Self-Help Movement; Kumarian Press: Sterling, VA, USA, 1985.

40. Kantowsky, D. Sarvodaya: The Other Development; Vikas: Sahibabad, India, 1980.

41. Saran, A.K. On the promotion of Gandhian studies at university level. Gandhi Marg 1979, 1, 363-381.

42. School of Non-Violence; Kumar, S., Ed.; Martin Luther King Foundation/Christian Action/ Housmans: London, UK, 1969; p. 6.

43. Sethi, J.D. Gandhi Today; 2nd ed.; Vikas: Sahibabad, India, 1979; p. 138.

44. Hutchinson, F. Making peace with people and planet: Some important lessons from the Gandhian tradition. In Towards Gandhian World Order; Misra, S., Ed.; Gandhian Studies and Peace Research Series; Concept: New Delhi, India, 2005; pp. 158-170.

45. Naess, A. Gandhi and Group Conflict: An Exploration of Satyagraha's Theoretical Background; Universitetforlaget: Oslo, Norway, 1974; p.10.

46. Naess, A. Self-realization: An ecological approach to being in the world. The Trumpeter 1987, 4, 35-42; Available online: http://trumpeter.athabascau.ca/index.php/trumpet/article/view/623/992 (accessed on 10 November 2010).

47. Haigh, M. Deep Ecology Education: Learning from Its Vaisnava Roots. Can. J. Environ. Educ. 2006, 11, 43-57.

48. Devall, B. The ecological self. In The Deep Ecology Movement: An Introductory Anthology; Drengson A.; Inoue Y., Eds.; North Atlantic Books: Berkeley, CA, USA, 1995; p. 107.

49. Sarkar, P.R. Stages of Psycho-Spiritual Sa'dhana. Calcutta, 19 April 1981. In The Electronic Edition of the Works of P.R. Sarkar, 6th ed.; Ananda Marga Publications: Kolkata, India, 2001.

50. Sarkar, P.R. How an Ideal Person Should Live from Subha's'ita Sam'graha 12, Calcutta, 1979. In The Electronic Edition of the Works of P.R. Sarkar, 6th ed.; Ananda Marga Publications: Kolkata, India, 2001; p. 2.

51. Sarkar, P.R. PROUT in a Nutshell; Ananda Marga Pracaraka Samgha: Kolkata, India, 1981.

52. Maheshvarananda, D.; Branch, M. The Progressive Utilization Theory (Prout): Alternative Economic and Spiritual Model for the Welfare of All. WorkingUSA 2010 13, 31-40.

53. Prout Institute. PROUT: A New Paradigm of Development; Available online: http://www.proutinstitute.org/index.html (accessed on 15 September 2010). 
54. Landever, B.; Maheshvarananda, D. "Art of Peace" International Conference in Venezuela. Venezuela Analysis, 11 May 2010. Available online: http://venezuelanalysis.com/analysis/2379 (accessed on 12 September 2010).

55. Ragu, K. Interview in Another Life Is Possible [DVD]; Prout Research Institute of Venezuela: Caracas, Venezuela, 2008.

56. Vandanananda, D. Prout in India. In Proceedings of the Proutist Universal Global Convention, Ananda Gaorii, Denmark, 20 July-27 July 2009; Proutist Universal Global Office: Copenhagen, Denmark, 2009; pp. 21-23.

57. Hatley, S.; Inayatullah, S. Karma Samnyasa: Sarkar's Reconceptualization of Indian Asceticism. J. Asian Afr. Stud. 1999, 34, 139-151.

58. Bussey, M. Education for Liberation: A Cornerstone of Prout. In Understanding Prout-Essays on Sustainability and Transformation; Karlyle, J., Towsey, M., Eds.; Proutist Universal Australia: Blacktown, Australia, 2009; Volume 1, pp. 78-103.

59. Alister, K. Why We Are Teaching Baba Nam Kevalam Meditation at the Ananda Marga River School. Neohumanist Education, 2001, p. 2; Available online: http://nhe.gurukul.edu/ openresources/bnk.htm (accessed on 10 November 2010).

60. Ghista, D.N. Gurukula University. In Proceedings of the Proutist Universal Global Convention, Ananda Gaorii, Denmark, 20 July-27 July 2009; Proutist Universal Global Office: Copenhagen, Denmark, 2009; pp. 17-21.

61. Neohumanist Educational Futures: Liberating the Pedagogical Intellect; Inayatullah, S., Bussey, M., Milojevic, I., Eds.; Tamkang University Press: Taipei, Taiwan, 2006.

62. Sarkar, P.R. Basic Differences in Attitude between the East and the West, Ranchi, 1969. In The Electronic Edition of the Works of P.R. Sarkar, 6th ed.; Ananda Marga Publications: Kolkata, India, 2001.

63. Cole, R.J. Forty years of chanting: A study of the Hare Krishna Movement from its foundation to the present day. In The Hare Krishna Movement: Forty Years of Chant and Change; Dwyer, G., Cole, R.J., Eds.; I.B. Taurus: London, UK, 2007; pp. 26-53.

64. Schweig, G. The Dance of Divine Love; Princeton University Press: Princeton, NJ, USA, 2005.

65. Cremo, M.; Goswami, M. Divine Nature: A Spiritual Perspective on the Environmental Crisis; Bhaktivedanta Book Trust: Los Angeles, CA, USA, 1995.

66. Bhaktivedanta Swami, A.C., Prabhupada. Bhagavad Gita as It Is; Bhaktivedanta Book Trust: Los Angeles, CA, USA, 1972; pp. 739-740, 615-617.

67. Prime, R. Vedic Ecology: Practical Wisdom for Surviving the Twenty-first Century; Mandala: Novato, CA, USA, 2002.

68. Bhakti Ragava. Make Vrindavana Villages in Support of Varnasrama Dharma; Varnasrama Book Trust: Hebri, India, 2007.

69. Rupanuga dasa. Solution-Isavasya (God-centred) farming. Quotation in: Sahadeva dasa. End of Modern Civilization; Bhagavata World Order Press: Hyderabad, India, 2008; pp. 413-414.

70. Bhakti Ragava. Varnasrama Education; Varnasrama Book Trust: Hebri, India, 2008.

71. Sahadeva dasa. End of Modern Civilization; Bhagavata World Order Press: Hyderabad, India, 2008. 
72. Petroff, A. Congo Farm Project-From starvation to sustainability. Small Farmer's Journal, 10 January 2010; Available online: http://smallfarmersjournal.com/congo-farm-project-fromstarvation-to-sustainability (accessed on 12 August 2010).

73. Our Development Model: Village Self Reliance; Working Villages International: Topsham, ME, USA, 2010; Available online: http://www.workingvillages.org/our-development-model.html. (accessed on 15 September 2010).

74. Berg, T.V.; Kniss F. ISKCON and immigrants: The rise, decline, and rise again of a New Religious Movement. Sociol. Quart. 2008, 49, 79-104.

75. Ahimsa Milk-Happy Healthy Cows; The Lotus Trust: Watford, UK, 2010; Available online: http://www.thelotustrust.org/index.php (accessed on 12 September 2010).

76. Chauhan, S.; Sita Rama das; Rita, N.; Haigh, M. Promoting Education for Sustainability in a Vaishnava (Hindu) Community. Appl. Environ. Educ. Commun. 2009, 8, 114-125.

77. Chauhan, S.C.; Sita Rama das; Haigh, M.; Rita, N. Awareness versus Intentionality: Exploring Education for Sustainable Development in a British Hindu Community. Sustain. Dev. 2010, doi:10.1002/sd.494; Available online: http://onlinelibrary.wiley.com/doi/10.1002/sd.494/abstract (accessed on 7 September 2010).

78. Garga Muni. Garga Samhita; Kusakratha das, Translator; Rasbihari Lal and Sons: Vrindavan, India, 2006; pp. 36-45.

79. Ikdasa. Hindu Plans for Environmental Change Launched at Oxford; OCHS (Oxford Centre for Hindu Studies): Oxford, UK, 2009; Available online: http://www.ochs.org.uk/news/hindu-plansenvironmental-change-launched-ochs (accessed on 4 August 2009).

80. Many Heavens, One Earth: Faith Commitments to Protect the Living Planet; Colwell, M., Finlay, V., Hilliard, A., Weldon, S., Eds.; Alliance of Religions and Conservation (ARC): Bath, UK, 2009; Available online: http://www.windsor2009.org/Windsorcommitmentslayoutfinal. pdf.pdf (accessed on 5 November 2010).

81. 'Go Veg, Go Green' Posters; Shri Swaminarayan Mandir BAPS (Bochasanwasi Shri Akshar Purushottam Swaminarayan Sanstha): London, UK, 2009; Available online: http://www. mandir.org/diwali/posters.htm (accessed on 25 April 2009).

82. Sri Venkateswara (Balaji) Temple of the United Kingdom Homepage. http://www.venkateswara.org.uk/ (accessed on 25 April 2009).

83. Krishna Avanti Primary School Homepage. http://www.krishna-avanti.org.uk/ (accessed on 25 April 2009).

84. The Bhumi Project; Lila das, G., Ed.; Oxford Centre for Hindu Studies: Oxford, UK, 2010; Available online: http://bhumiproject.org/history/ (accessed on 11 November 2010).

85. O'Brien, J.; Palmer, M. The Atlas of Religion; Earthscan: London, UK, 2007.

86. Hunter, P. Major Religions of the World Ranked by Number of Adherents; Adherents.com: Dallas, TX, USA, 2007; Available online: http://www.adherents.com/Religions_By_Adherents.html (accessed on 1 August 2009).

87 Gardner, G.T. Inspiring Progress. Religions' Contributions to Sustainable Development. (A Worldwatch Book); W.W. Norton: New York, NY, USA, 2006.

88. Freire, P. Pedagogy of the Oppressed; Continuum: New York, NY, USA, 1970. 
89. Kumar, K. What is worth teaching, (1986-7). In What Is Worth Teaching, 3rd ed.; Kumar. K., Ed.; Orient Longman: Hyderabad, India, 2004; pp. 1-23.

90. Kumar, K. Political Agenda of Education: A Study of Colonialist and Nationalist Ideas, 2nd ed.; Sage: New Delhi, India, 2005.

91. Bharati, A. The Hindu Renaissance and Its Apologetic Pattern. J. Asian Stud. 1970, 29, 267-288.

92. Partho. Integral Education: A Foundation for the Future; UBSPD: New Delhi, India, 2007.

93. Huppes, N. Psychic Education, A Workbook; Sri Aurobindo Education Society: New Delhi, India, 2001.

94. Tillman, D.; Colomina, P.Q. Living Values Educational Programme: LVEP Educator Training Guide; Health Communications: Deerfield Beach, FL, USA, 2000.

95. Environmental Care-Deepening Roots; The Art of Living Foundation: Bangalore, India, 2009; Available online: http://www.artofliving.org/environmental-care-home (accessed on 4 November 2010).

96. The History and Philosophy of Sathya Sai Education; Sri Sathya Sai Books and Publications Trust: Prasanthi Nilayam, India, 2007; Available online: http://www.saispiritualeducation.com/ files2007/GlobalOverview/Chapter1_30Jun07.pdf (accessed on 4 November 2010).

97. Activities: Environmental Care; BAPS Swmainarayan Sanstha: Amdavad, India, 1999; Available online: http://www.swaminarayan.org/activities/environmental/index.htm (accessed on 15 September 2010).

98. Giri, A.K. Religion and Development in Contemporary India: The Self-Study Mobilization of Swadhyaya and the calling of transformations. Presented at the International Conference on "Religion and Development: Crisis or New Opportunities", Vrije Universitet, Amsterdam, The Netherlands, 14-15 June 2007; Available online: http://www.bezinningscentrum.nl/ Religion_Development/giri.pdf . (accessed on 5 November 2010).

99. Macy, J.; Brown, M.Y. Coming Back to Life: Practices to Reconnect Our Lives, Our World; New Society Publishers: Gabriola Island, Canada, 1998.

100. Hansmann, R. "Sustainability Learning": An introduction to the concept and its motivational aspects. Sustainability 2010, 2, 2873-2897.

101. Vivekananda. Conversations and Dialogues, 1899. In The Complete Works of Swami Vivekananda; Advaita Ashrama: Calcutta, India, 1989; Volume 7, p. 183.

102. Tagore, R. Towards Universal Man; Asia Books: Mumbai, India, 1961; p. 43.

103. Tagore, R. The Religion of Man; Monkfish: Rhinebeck, NY, USA, 1930; p. 42.

104. Gandhi, M.K. Hindu Dharma; Orient: Mumbai, India, 1978; p. 139.

105. Orr, D. The Earth in Mind; Island Press: Washington, DC, USA, 1994.

106. Berry, T.M. The Great Work: Our Way into the Future; Belltower: New York, NY, USA, 1999.

107. Paden, M. The Ahmedabad Declaration. In Education for Sustainable Development; Chalkley, B., Haigh, M., Higgitt, D., Eds.; Routledge: London, UK, 2009; pp. 245-246.

108. Tomalin, E. Hinduism and International Development: Religions and Development Background Paper; Working Paper No. 19; Religions and Development Research Programme, University of Birmingham: Location, UK, 2009; p. 51; Available online: http://www.dfid.gov.uk/R4D/PDF/ Outputs/ReligionDev_RPC/WP19.pdf (accessed on 11 November 2010). 
109. Sarkar, P.R. Some Educational Policies; Some Hints on Education (1980-1981). In The Electronic Edition of the Works of P.R. Sarkar, 6th ed.; Ananda Marga Publications: Kolkata, India, 2001.

(C) 2010 by the authors; licensee MDPI, Basel, Switzerland. This article is an open access article distributed under the terms and conditions of the Creative Commons Attribution license (http://creativecommons.org/licenses/by/3.0/). 